\title{
ALA candidates share their plans for the foture
}

\section{Be an informed voter in the $A L A$ elections}

5 or this exclusive $C E R L$ News feature, candidates for ALA president and treasurer were asked why they are seeking office and what they hope to accomplish if elected. CERL News hopes these statements will aid you when you vote for AIA officers in this spring's ballots.

\section{Hardy Franklin}

Wby do you want to be president of ALA? The unifying principle of my career has been to measure everything I do in terms of customer service. It will be the central theme of my presidency. The publics we serve need more attention, incentive, opportunity, and even more prompting to make them feel invited, welcomed, and accepted.

I have demonstrated my ability as a leader who can be visionary



Hardy Franklin and innovative, yet able to combine traditional services with new creative approaches. I am able to motivate and work effectively with staff, trustees, elected officials, and the general public to provide quality and equitable services, programs, and activities.

My career steps have been the right ones to qualify me to take the mantle of leadership of ALA. I have sacrificed and worked creatively, efficiently, and effectively in these changing times. At this juncture of my career I can be an effective spokesperson and model for the profession.

What do you bope to accomplish as president? In these chaotic times, there is an important role for libraries and we need to carve out

our space, promote our role, organize our support, and broaden, refine, and target our services. There are many types of librarians and kinds of libraries doing really fantastic work and providing excellent service. As national spokesperson I want to raise the nation's consciousness and heighten awareness of the essential customer service role of today's libraries in American society.

My goal is simply to fill university and other types of libraries with more people. A know]edgeable, supportive community of users will help level our paths in hard times, stave off budget cuts, and provide influence and support on many levels. Adequate funding, literacy, cultural diversity, equal access, networking, and resource sharing are vital to service. Intellectual freedom must be genuine and include training for librarians before problems occur. Libraries and library schools must be kept open, sufficiently funded, and staffed by qualified and equitably paid personnel.

As president of ALA I will pursue these goals even more strenuously than I have on the local level.

\section{Kathleen de la Peña McCook (Heim)}

Why do you want to be president of ALA? This question is inextricably entangled in question two. For each position I have sought in my career-dean of a school of library and information science, dean of a graduate school, president of ALISE-my reason has been to accomplish goals that I viewed as crucial and that I felt I had developed the right combination of skills to move toward accomplishing. I

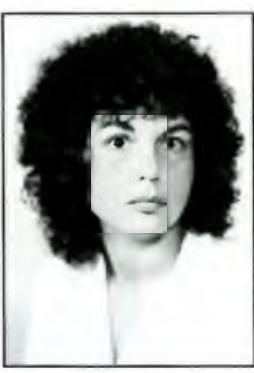

Kathleen de la Peña McCook (Heim)

have been a librarian for 20 years; I have been 


\section{The Wilson Indexes on}

Magnetic Tape!



Versatility-Accessibility-Affordability



ring the renowned Wilson Indexes to your institution with easy, unlimited local electronic access. WILSONTAPE provides machine-readable monthly tapes for each database-in USMARC or Wilson-tagged format-making the data accessible with the same system of commands and protocols as your online catalog.

\section{The Premier Choice for System-Wide Data Access}

\section{WILSONTAPE Service} provides access to Wilson's renowned databases on a 24-hour basis. Patrons can access data from homes, offices, or dormitories with the same hardware and software used for the library's public access catalog or other locallyloaded databases. The number of simultaneous users is limited only by system capacity and you pay the same annual fee regardless of how frequently the files are accessed.

\section{Create Your Own Custom- ized Electronic Library}

By selecting the databases that best meet your needs, you create a customized databank that:

- Maximizes the use of existing hardware and software

- Enhances use of periodical and book holdings

- Promotes simultaneous use by multiple searchers on a round-the-clock basis

- Enables unlimited off-site access to centralized reference holdings

- Reduces training time by providing easy access to data with familiar search software

- Eliminates costly connecttime charges

\section{Customized Databanks at Individualized Rates}

With an innovative, easyto-understand pricing structure, WILSONTAPE Service is affordable to institutions of every size. An initial subscription to any database tape includes data from 1989, plus monthly updates for the forthcoming year. Retrospective data prior to 1989 is also available.

\section{Call Toll-Free} 1-800-367-6770, Ext, 2758, for more information and a price quotation.

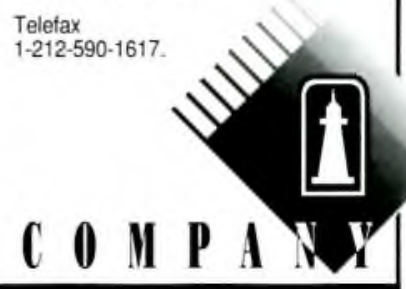

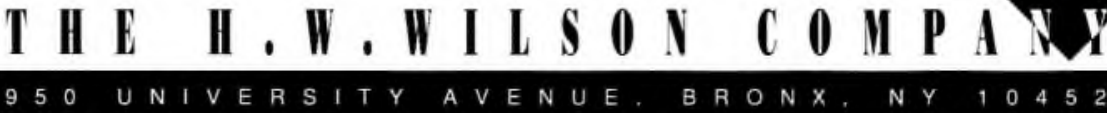


a university administrator for nine. I am faced with the choice at this time to move to higher levels of university administration that take me farther from my home discipline or to turn my attention to the mission of enhancing learning and ensuring access to information for all through the venue of the American Library Association. I have chosen to try for the latter.

What do you bope to accomplish as president? Throughout my career my daily work has been a syncopated counterpoint of expansive action to implement policy and one-on-one interaction with students and colleagues. On a given day I might present a plan to the state Board of Regents to enhance minority recruitment and then meet in my office with a student whose research project has gone awry. If I had to characterize my work life it would be as a daily juxtaposition of the general and the particular. The presidency of the American Library Association would present a similar work life. The president sets an agenda, makes committee appointments, and represents the membership in the context of one-on-one interactions with users and colleagues.

As a librarian I have continued to work on issues of basic literacy through one-on-one tutoring of minority children while at the same time writing and developing articles and studies on how basic education can promote lifelong learning. As president of the American Library Association my goals would be to articulate my very strong daily awareness of the needs of users for access to information and life-long learning through intensive development of the priorities set for the "Decade of the Librarian."

If I'm elected, my presidency would take place midway through the "Decade of the Librarian" and it would be my intent to develop programs and studies along the lines of the vision statement on librarians as fighters, leaders, partners, experts, models, and professionals empowering others. My ALA involvement has provided me substantive association experience in this area as I have served as chair, member, or task force member of the various committees of the Office for Library Personnel Resources for 15 years. I also have solid experience on gender issues as chair of the Committee on the Status of Women in Librarianship, member of the ERA Task Force, and author of books and articles on issues relating to affirmative action and pay equity. Commitment to multicultural diversity - a requisite bedrock foundation for an effective presidency-may be seen in my work developing an ALA Goal Award for Minority Recruitment, service on the Giles Scholarship jury, and writing on the need for greater ethnic diversity in my recent book, Occupational Entry.

As a university administrator I have broad experience working with faculty in dozens of disciplines and have had responsibility for their professional development. Combining this experience with my primary work-education of librarians positions me well to work to achieve the goals set forth by the AlA membership for the "Decade of the Librarian."

I hope to accomplish much as ALA president. In addition to advancing a personnel-related agenda, I look forward to identifying a multicultural cadre of committee appointments looking for colleagues whose daily one-on-one commitment is realized through their effective movement of best practice to policy.

The mission statement of the American Library Association is to enhance learning and ensure access to information for all. It is my hope that during my presidency I will lead the association toward the accomplishment of these ideals.

\section{Norman D. Stevens}

Why do you want to be president of $A L A$ ? Why not? As a boy getting my first library card I dreamt of someday being president of ALA. As a student in the Graduate Library School at Rutgers my contacts with several presidents furthered my dream. Now I have a chance, albeit a slim one, to fulfill that lifelong ambition. As director of the Molesworth Institute, I want to be president of ALA so that I can bring to AIA the same com-

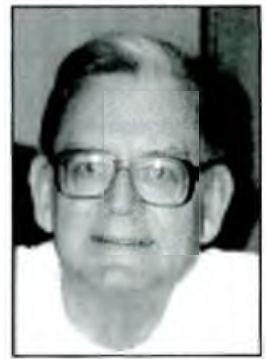

Norman Stevens bination of fun, madness, and true reality that pervades the work and play of the Molesworth Institute. I want to be president of ALA to demonstrate to the entire membership that anyone can aspire to, and perhaps attain, the highest office of Our Profession.

What do you bope to accomplish as president? Not much! ALA has far too many activities, agenda items, committees, programs, and other ventures as it seeks to be all things to all of its members. I hope that ALA might benefit from a pause in its frantic rush. By doing less, 
even if only for a brief time, and enjoying the fun of librarianship, ALA could become a more enjoyable organization. As a life member, but an outside casual observer who has had no direct involvement with ALA for many years, I believe that I can accomplish much that those who have become enmeshed and entrenched in ALA's organizational bureaucracy and morass cannot. While I would make every effort to reduce the scope of ALA's activities during my term of office, I recognize that there are limits to the long-term impact of such an effort. I would, therefore, propose the adoption of severe limitations on terms of office on the ALA Council and all other official positions including committee memberships. I would also propose that serious consideration be given to dismantling the central bureaucracy of ALA and setting the divisions and chapters free to go their own way enabling them to form, if they wish, a commonwealth structure that would better serve their needs and the needs of ALA's members.

\section{Bernard A. Margolis}

Wby do you want to be treasurer of ALA? I want to be the treasurer of the American Library Association because I believe that I can make a difference! ALA is responding to the tough times which many of us face in our own institutions. With a total budget of over $\$ 25$ million, our association ended this year with just $\$ 22,000$. If someone had sneezed we could have been in the deficit column. As a manager with extensive experience in

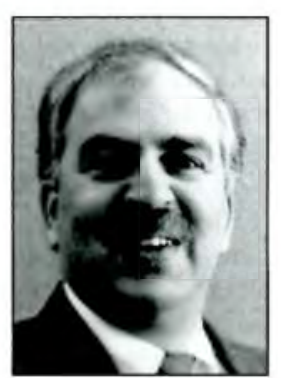

Bernard Margolis the use of financial resources, I want to help our association. I direct a library with a $\$ 10$ million budget. I serve as one of ALA's three endowment trustees, managing almost $\$ 5 \mathrm{mil}$ lion. Inside and outside of my library work I have committed myself to using my financial management skills. I was treasurer of the Michigan Library Consortium. I was chairman of the United Way Allocations Committee, spending over $\$ 3$ million for community services. As ALA is forced to cope with today's financial realities, tough decisions will need to be made which will permit our association to address and respond to member needs and to the values which we believe are important. I believe my experience, skills, and desire can bring our association through the tough times ahead.

What do you hope to accomplish as treasurer? I hope, first and foremost, to bring creativity to the position of treasurer. As a member of ACRL, I have seen the creative energies of our members put to good use. I believe our association can benefit from the creative talents of our members. Rather than looking at diminishing what we do for our members and for the larger community, I think we need to look at the opportunity to be more efficient and to use our resources more creatively. Rather than discussion, for instance, of eliminating our toll-free member line, I imagine shopping for alternative 800 carriers who can provide the same service at a lower cost. Rather than considering eliminating conference shuttle buses, I envision conducting fundraising to support the cost of this important service. And the list goes on. I believe my most important accomplishment will be fiscal restraint coupled with the effective use of creativity.

\section{Judith A. Sessions}

Why do you want to be treasurer of ALA? The position of ALA treasurer is critical to ensuring the future success and integrity of the association. ALA has become so large and complex an organization that there is a danger that the bureaucracy will drive the members instead of being driven by them. A grassroots approach to management will foster a more satisfied and active membership, resulting in a healthier, more focused organization.

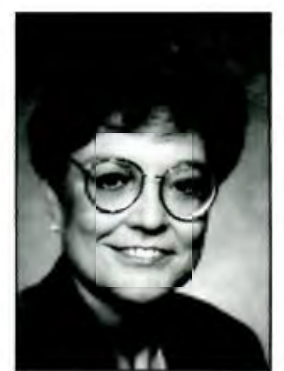

Judith Sessions As treasurer I want to play a key role in reassessing the values and carrying out the priorities and vision of its members through the budgeting process. During my two decades of service to ALA and the library profession, I have gained the financial knowledge, experience, planning skills, and leadership ability to help guide the fiscal affairs of ALA toward that goal.

What do you hope to accomplish as treasurer? As treasurer of ALA my first goal will be to develop a budget that supports the priorities of the association, as stated in the ALA Strate- 


\section{We'll give you a spectacular view of the science world.}

NEW IN 1992:

Science Citation Index Compact Disc Edition with ABSTRACTS

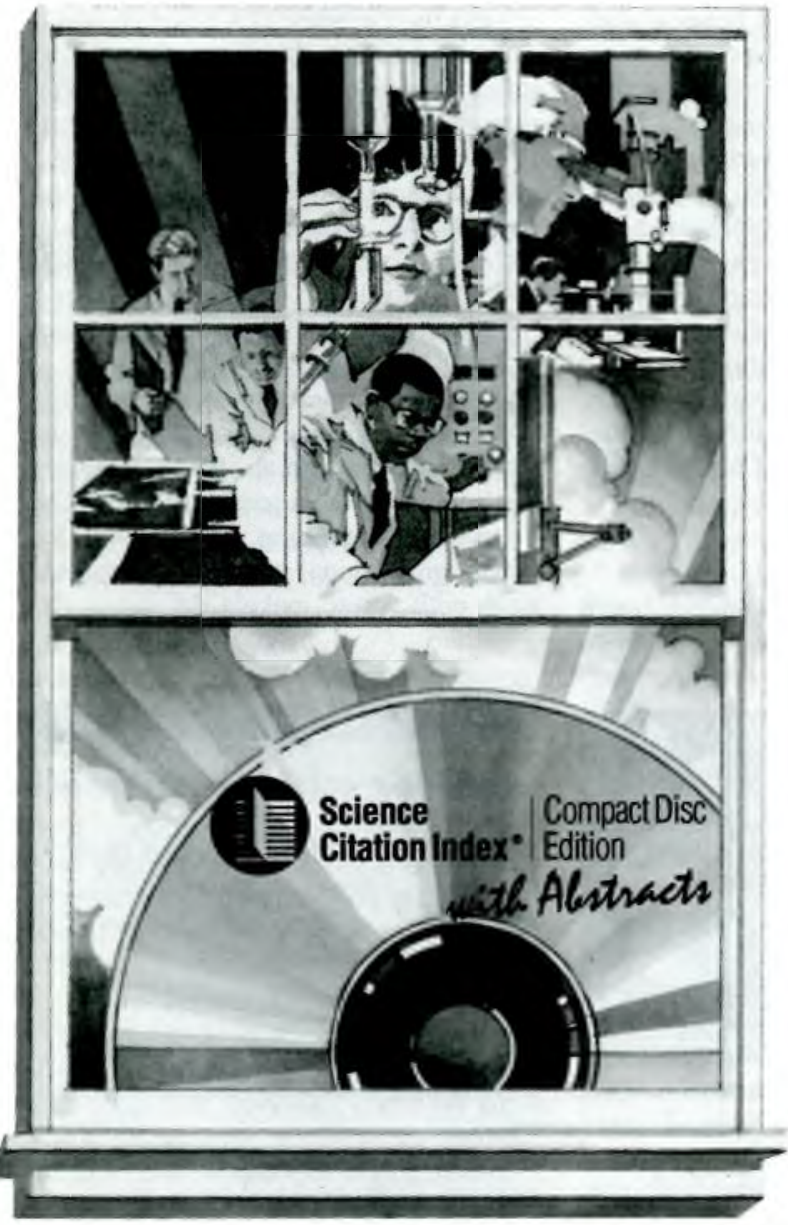

The best thing is, you need go no farther than your computer terminal - where you'll see it all in the Science Citation Index Compact Disc Edition.

With simple keystrokes, you're viewing the bibliographic records of 3,100 leading science journals... and rumning lightning-fast searches to retrieve data on thousands of research topics.

Another keystroke activates Related Records ${ }^{\mathrm{TM}}$, the powerful searching mechanism available only from ISI ${ }^{*}$. When you find one pertinent article, you're automatically led to many more, even if they have no title words in common! It's information you'd find no other way information that could have a dramatic impact on your research.

And newly available in 1992, searchable abstracts to make your search session even more complete. Reserve a free trial copy or demo diskette of the $\mathrm{SCI}^{*}$ CDE by calling $800-336-4474$, operator R467, or write the ISI office nearest you.

Institute for Scientific Information ${ }^{\star}$

3501 Market Street, Philadelphia, PA $19104-3389$ U.S.A. Telephone: (215) 386-0100, Fax: (215) 386-2911 ISI European Eranch: 132 High Street, Uxbridge, UB8 1DP U. K. Telephone: +44-895-270016

Fax: +44-895-256710 Telex: 933693 UKIS 
gic Plan. It is essential that the association analyze its fiscal affairs in a systematic manner in order to ensure that its valuable resources are used to further the essential values shared by its members. As treasurer of ALA I will endeavor to de-politicize the relationship between the elected and staff leadership of the association and promote a positive working atmosphere which permits the free exchange and evaluation of ideas. I will strive to develop a positive and mutually respectful team relationship between the ALA treasurer, the ALA financial staff, and top management. I will search vigorously for creative ways to generate additional income, thereby strengthening the association's financial base while offsetting the need for dues increases. To provide more timely, correct, and comprehensible financial information, I will work with staff to integrate new automated systems for fiscal management and planning. During uncertain financial times, our association can only remain healthy through sound financial planning. With my experience, skills, and proven leadership, ALA can maintain traditional values and prepare itself for the transition to the 21 st century.

\section{Ann Symons}

Why do you want to be treasurer of ALA? I seek your vote because I care about library services in my hometown and I care about library services in your hometown. ALA is a rich association; rich in financial assets, rich in people resources. As your treasurer I will ensure that our assets are protected and that we use our resources to significantly advance librarianship and benefit library users.

ALA is not a library,

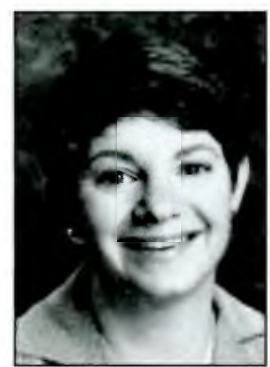

Ann Symons it is a complex association which runs several businesses to meet member needs. Each year we must raise all of the dollars we need to fund our priorities. Our collective resources can become even more powerful if we view every dollar of member dues - and every hour of volunteer time-as an investment in the future of library services.

What do you bope to accomplish as treasurer? As your treasurer my commitment is to make sure our values underlie our financial decisions, implement sound financial planning systems, build a full-fledged development program, ensure that our dues are affordable and our divisions and offices healthy, make information available and understandable so that we have a basis for sound decision making, and enhance our endowment.

As a chapter councilor, a member of the Executive Board and its Finance and Audit Committee, and Chair of the Executive Board Procedures Review Committee, I know my way around the complex ALA financial and organizational structure. My proven record at local, state, and national levels has resulted in my election to the following offices: AlA Executive Board, ALA Council as Alaska's chapter councilor, treasurer of the Alaska Library Association (AkLA), president of AASL/Alaska, and AkLA's Executive Board. As a school librarian, a former academic librarian, and a public library friend, I understand the issues facing all types of libraries.

I know the questions to ask. I will use my knowledge and experience to be sure that ALA has the answers and the financial resources to fund solutions - solutions to problems like public awareness, funding, censorship, diversity, access, professional status, and education. I will work with you to make a difference.

\section{Call for sci/tech abstracts}

ACRL's Science and Technology Section's Forum for Science and Technology Research Committee invites abstracts describing recent research or work in progress of interest to science and/or technology librarians. Individuals will be selected to present reports of their research at the 1993 ALA Annual Conference in New Orleans. Research should focus on timely, relevant, and significant aspects of science and/or technology librarianship. Proposals should be limited to one page and contain an abstract of no more than 250 words, the researcher's name, institution, phone number, and e-mail address (when available). Deadline for submissions: January 1, 1993. Send abstracts to Katie Clark, Head, Life Sciences Library, E205 Pattee Library, Pennsylvania State University, University Park, PA 16802; fax (814) 865-3708; or bitnet: kec@psulias. 